University of Nebraska - Lincoln

DigitalCommons@University of Nebraska - Lincoln

Egyptian textiles and their production: 'word' and 'object'

Centre for Textile Research

$2-2-2020$

\title{
Flax growing in late antique Egypt: evidence from the Aphrodito papyri
}

Isabelle Marthot-Santaniello

University of Basel

Follow this and additional works at: https://digitalcommons.unl.edu/egyptextiles

Part of the Africana Studies Commons, African Languages and Societies Commons, Classical Archaeology and Art History Commons, Fiber, Textile, and Weaving Arts Commons, History of Art, Architecture, and Archaeology Commons, and the History of Science, Technology, and Medicine Commons

Marthot-Santaniello, Isabelle, "Flax growing in late antique Egypt: evidence from the Aphrodito papyri" (2020). Egyptian textiles and their production: 'word' and 'object'. 10.

https://digitalcommons.unl.edu/egyptextiles/10

This Article is brought to you for free and open access by the Centre for Textile Research at DigitalCommons@University of Nebraska - Lincoln. It has been accepted for inclusion in Egyptian textiles and their production: 'word' and 'object' by an authorized administrator of DigitalCommons@University of Nebraska - Lincoln. 


\title{
Flax growing in late antique Egypt: evidence from the Aphrodito papyri ${ }^{1}$
}

\author{
Isabelle Marthot-Santaniello
}

\section{Introduction: The unexpected scarceness of textual evidence for flax cultivation}

While flax culture was a major economic sector in Egypt throughout antiquity and the medieval period, one can only agree with John R. Rea, the editor of P. Coll.Youtie II 68, when he says: "it has not escaped notice that surprisingly little information about [flax and linen] has been recovered from the Greek papyri”. ${ }^{2}$ By way of example, the specific word for the flax plant, linokalame $\overline{,}^{3}$ appears in Greek papyri only in around 60 of more than 60,000 published texts. ${ }^{4}$ More specifically, the agricultural conditions set to produce flax are seldom visible in the texts: little more than twenty documents are relevant to this topic.

A first explanation for this lack of data concerning flax in the papyri is that the main region of flax production was the Delta, which has yielded almost no papyri because of its humid climate. ${ }^{5}$ In a recent study, Katherine Blouin convincingly gathered the evidence for flax production in the
Delta, specifically the Mendesian nome, underlying how this area enjoyed suitable conditions for flax growing. As she points out, Pliny the Elder, our main source on flax culture in Roman Egypt, listed four varieties of Egyptian linen, three of which are associated with towns located in the Northern Delta: Tanis, Pelusium and Bouto. ${ }^{6}$

This explanation is not fully satisfactory because, while the Delta was probably the main region of production, flax was also cultivated in the Valley and in such proportions that it should be more visible in the texts. Several sources can be mentioned to attest, if needed, that flax was also a cash crop in Upper Egypt. First, the fourth variety listed by Pliny refers to the city of Tentyris, modern Dendera. Medieval sources also mention flourishing centres of flax and linen in this part of the country: "When the merchant Ibn Hauqal described the countryside of Egypt around the middle of the tenth century, the distribution of cash crops was dominated by a certain specialization, with Aswan (Syene) noted for its abundance of date palms, Ashmunein for flax,

Published in Maria Mossakowska-Gaubert, ed., Egyptian Textiles and Their Production: 'Word' and 'Object' (Hellenistic, Roman and Byzantine Periods) (Lincoln, NE: Zea Books, 2020). doi 10.32873/unl.dc.zea.1087

1. Preliminary remarks on the present topic were part of my doctoral dissertation (Marthot forthcoming), defended in 2013. The present work was achieved as part of the SNSF-funded project $n^{\circ} 100015$ 162963 "Change and Continuities from a Christian to a Muslim Society - Egyptian Society and Economy in the $6^{\text {th }}$ to $8^{\text {th }}$ centuries". I would like to express my gratitude to Professor Jean-Luc Fournet and Mrs Florence Lemaire for providing access to their unpublished material, and to Mrs Jennifer Cromwell for her careful proofreading of this article.

2. P. Coll.Youtie II 68, introduction p. 457. Coptic documents seem more numerous on this subject.

3. Linon can refer both to flax and linen products. For a discussion on Greek words referring to flax, see Mayerson 1998, p. 223225; for a lexicographical study, see Georgacas 1959, p. 253-269.

4. Papyri.info last consulted on August 2018. The present paper is mainly focused on Greek papyri but also draws upon Coptic evidence in the discussion.

5. This explanation for the limited evidence furnished by the papyri is given, for example, in the introductions to $P$. Coll.Youtie II 68, introduction p. 459 and to P. Oxy. XLV 3254-3262, p. 128.

6. Blouin 2014, p. 236. 
'Fayyum' (the former Arsinoe) for fruit orchards and rice cultivation, Bahnasā (Oxyrhynchus) for its diversified textile industry, and so on". ${ }^{7}$ In the documents from the Cairo Geniza, dating from the $11^{\text {th }}$ century, twenty-eight varieties of flax are mentioned, "some of them are named for the location in which they were cultivated". ${ }^{\text {These }}$ places are not all identified but at least we can recognise from Upper Egypt the "Asyūṭī (Suyūțī), Ashmūnī, Ițfīḥ̂̄" and "Fayyūmī". ${ }^{9}$ Indeed, a few papyri from Ashmunein (Hermopolis) and a more important group of a dozen papyri from Oxyrhynchus mention flax growing in these two cities in the $4^{\text {th }}$ century AD. ${ }^{10}$ Recently, Jennifer Cromwell studied textile production in Western Thebes as documented by Coptic papyri from the $6^{\text {th }}$ to the $8^{\text {th }}$ century and she analysed the attestations of flax production, in particular on land owned by the monastery of Epiphanius. ${ }^{11}$ At the important monastery of Apa Apollo at Bawit in the Hermopolite nome, although its important body of documents illustrates wheat and wine production, only one text alludes directly to flax growing: a $7^{\text {th }}$ - or $8^{\text {th }}$-century list of wine distribution for the workers hired for the harvest of flax. ${ }^{12}$

\section{Who grew flax? Weavers and agricultural activities}

Another explanation for the low number of papyri mentioning flax growing has been offered by Ewa Wipszycka in her seminal study of the textile industry in Roman Egypt: "Malheureusement, les sources gardent le silence au sujet de la participation des paysans au travail du lin brut; cet état des choses n'est pas uniquement dû au hasard des trouvailles des documents. Le travail du lin était exécuté par une population illettrée et, pour la plupart, non grecque; il n'était pas grevé d'un impôt spécial, il n'exigeait pas l'intervention de spécialistes". ${ }^{13}$

The most logical explanation as to the silence of the available sources would be that flax growing was common, done by illiterate peasants in almost any village as a domestic activity that sometimes produced surplus, which was sold to the weavers, and all this without the need of written documents. The same idea is further developed when Wipszycka listed the three ways through which a weaver could get his material, which is the "filé" or yarn. The first is to produce it from beginning to end by cultivating himself a plot of land with flax. The second is to receive it from the customer, who orders a piece of work. The third option is to buy it. ${ }^{14}$ Concerning the first case, in which a weaver cultivates flax himself, Wipszycka warns the reader: "Je crois qu'il ne faut pas surestimer cette dernière source, d'autant plus que les renseignements à ce sujet sont très restreints. Une liaison aussi étroite entre l'industrie textile et l'agriculture nous obligerait à admettre un niveau très bas de la première, ce qui n'est pas confirmé par l'ensemble de sources". ${ }^{15}$ For Wipszycka, the occupation of weaving was on a higher social level than that of agriculture. She had indeed gathered a few texts in which a weaver is seen cultivating flax: three land leases in which the lessee is a weaver who will sow flax himself (SPP XX 113 (AD 401), P. Cair.Masp. I 67116 (6 $6^{\text {th }}$ century), P. Lond. III 1072 ( $7^{\text {th }}$ century), and a fourth document quickly summarized as follows: "Dans P. Flor. III 296 [6 $6^{\text {th }}$ century], un tisserand figure comme propriétaire". ${ }^{16}$

\section{Weavers growing flax themselves in Aphrodito: some coveted tenants}

Among these four texts, the second and the fourth are from the village of Aphrodito (Kom Ishqaw), located between Lycopolis (Assiut) and Panopolis (Akhmim) in the middle of the arable land on the west bank. This village is famous as the best-documented single village of late antiquity, on account of a thousand papyri found during the early $2 \mathrm{O}^{\text {th }}$ century. ${ }^{17} \mathrm{New}$ studies, recently undertaken under the

7. Banaji 2001, p. 6 and note 1, referring to Ibn Ḥauqal's book entitled Configuration de la terre (Kitāb Șūrat al-arḍ).

8. Gil 2004, p. 84; Blouin 2014, p. 238 underlines that this naming practice concerns more than half the cases.

9. Gil 2004, p. 84 and note 11, which gives the location of some of the less obvious denominations, e.g. Tamawi being a village near Assiut.

10. See P. Coll.Youtie II 68, introduction p. 457-458 and P. Oxy. XLV 3254-3262.

11. Cromwell 2017, p. 215-216.

12. P. Brux.Bawit 49. Other evidence of flax production in the Hermopolite is given by CPR IV 48 (Busiris, AD 625), a contract in which fourteen villagers commit to deliver linen to a Persian official. On this text, see recently Delattre 2018, p. 212-215.

13. Wipszycka 1965, p. 20; see also Bransbourg 2016, p. 328 and note 77.

14. Wipszycka 1965, p. 44.

15. Loc. cit.

16. Ibid. p. 21, note 18.

17. For a historical overview of these finds, see Marthot 2016a, p. 161-162. 
direction of Jean-Luc Fournet, focus in particular on the largest group of texts known as the "Dioscorus archive", which contains almost 700 papyri that span the entire $6^{\text {th }}$ century. ${ }^{18}$ Among them, nearly 100 land-leases and receipts were gathered and studied by Florence Lemaire, providing a better understanding of the archive. P. Flor. III 296, which was quickly characterized by Wipszycka as featuring a weaver mentioned as landlord, is in fact a draft of a letter similar to a petition, ${ }^{19}$ and the situation described is much more complex. Jean-Luc Fournet, who is preparing a re-edition of this text, argues a dating between 548 and 565 and identifies the handwriting as that of Dioscorus himself. In this letter, Dioscorus complains to an unknown recipient/addressee about Papnouthis, a village headman (protokōmètēs) ${ }^{20}$ who, among other misdeeds and without justified reasons, had arrested all the weavers (linoüphoi in line 40) from the adjacent village to the east, called Phthla. Dioscorus tried to have three of them immediately released, because they worked every year in his fields and paid his taxes due in gold. ${ }^{21}$ Papnouthis refused: he had already forced all the weavers to sign documents committing them to sow flax for him and he even asked them for an advance payment of taxes. Dioscorus begs the recipient of this letter to give orders so that these men, "who have always sown flax" for him, can return to him so that he will be able to pay taxes.

Manpower was not specifically lacking in Aphrodito, and private account books demonstrate that many workers cultivated Dioscorus' fields. ${ }^{22}$ P. Flor. III 296 illustrates clearly that having weavers cultivating flax in one's field was sufficiently profitable that some local figures used force to acquire them. The arrested weavers were apparently forced to sign an agreement with Papnouthis instead of dealing with Dioscorus as they usually did.

The other document from the archives that Wipszycka mentioned as being a land-lease attesting that weavers cultivated flax actually provides a more precise idea of the kind of agreement that Dioscorus may have had with weavers. In P. Cair.Masp. I 67116 (16 Phaophi /15 October 548), Biktōr son of Apollōs, a weaver (linoüphos), declares he is ready to sow with flax one aroura (c. 3,000 $\mathrm{m}^{2}$ ) that he has just rented from Dioscorus and that he owes him for the "rent, seeds and irrigation" ${ }^{23}$ one solidus minus two carats, i.e. 22 carats, which he will pay at the third tax instalment (katabolē). ${ }^{24}$ He pledges all his belongings as a warranty.

This type of agreement is peculiar. Typically, in agricultural leases from Aphrodito, the tenant only pays for the rent of the land, on which he can cultivate whatever he wishes. Irrigation costs and supply of seeds can be the object of special agreements between the landlord and the tenant. ${ }^{25}$ At this period, the rent for one aroura of land, without irrigation or seed provided, is around five artabai of wheat. ${ }^{26}$ According to a recent study, one solidus corresponds to ten artabai of wheat and thus one artaba corresponds to 2.4 carats. ${ }^{27}$ A rent of five artabas is therefore worth 12 carats. Details with which to evaluate the cost of irrigation and seed are lacking. ${ }^{28}$ Even if these extra costs are taken into account, the rent agreed by the weaver in P. Cair.Masp. I 67116 remains intriguingly high. ${ }^{29}$

The lease P. Cair.Masp. I 67116 and the petition P. Flor. 296 attest that it was a matter of importance that weavers sowed flax in the fields themselves. One could wonder if there was a technical skill or a specific gesture for this operation. Ancient Egyptian reliefs depict different movements

18. Fournet 2008, p. 307-343 (list of texts in Appendix 2); see Fournet 2016, p.121 for a distinction among the Byzantine papyri. 19. In his forthcoming re-edition, Jean-Luc Fournet labels this text as "supplique épistolaire".

20. There is, however, an ambiguity as to whether Papnouthis is one of the heads of Aphrodito or of the neighbouring village of Phthla.

21. Lines 43 to 45 .

22. See, for example, P. Cair.Masp. III 67325 (various texts dated from AD 554 to 585).

23. The Greek words that are used are phoros, spora and ardeusis.

24. The solidus was a gold coin that could be subdivided into 24 carats (keratia).

25. See e.g. P. Michael. 46 (AD 559).

26. Rents are often difficult to establish, since the texts have preserved either the total amount and not the size of the rented property, or the size and not the amount. In P. Michael. 43 from AD 526, a geōrgion (i.e. a property with irrigation equipment) has an annual rent of 5 artabai (two-thirds wheat and one-third barley) per aroura, see the commentary in Keenan 1980, p. 147 and note 7. In P. Hamb. I 68 from AD 548, the rent of the arable land is 4 artabai of wheat and 1 artaba of barley per aroura. In P. Vat.Aphrod. 1 (discussed below), the rent is 5 artabai of wheat per aroura in a well-equipped property.

27. Bransbourg 2016, p. 320.

28. It is usually accepted that 1 artaba of wheat is required to sow 1 aroura. The price of 1 artaba of flaxseed is unknown and flax can be more densely planted than wheat, so a higher quantity of seed may be needed for the same surface.

29. The same rate of 1 solidus per aroura is attested in Thebes but also with variations, see Cromwell 2017 , p. 215 and note 16. 
for sowing flax than wheat. For example, in the tomb of Urarna at Sheikh Saïd (Middle Egypt) dating from the Middle Kingdom ( $21^{\text {st }}$ to $18^{\text {th }}$ century $\mathrm{BC}$ ), "the man sowing cereal grain uses an overarm action, while the man scattering the flax seeds uses an underarm movement which is typical for the sowing of this crop". ${ }^{\circ}$ The harvest of flax also differs from wheat since the plants are "pulled rather than cut, in order to obtain as long and straight a length of fibre as possible", ${ }^{11}$ an operation made easier by the fact that flax has thin and shallow roots. Although flax certainly needed specific treatment, these operations do not seem so complicated that any peasant with a little experience could not achieve them. Another parameter seems more relevant to explain what is at stake when weavers cultivated flax themselves: they must have had a good knowledge of the plant, and the younger the plant is harvested, the finer the thread. Therefore, if they are in charge of the agricultural operation, they can decide what quantity to harvest and when in order to produce fine or coarse thread. ${ }^{2}$

Growing flax may have been the only agricultural operation with which a weaver was or chose to be concerned. The special agreement in which the landlord provided seed and dealt with irrigation costs may therefore have been practical for a person with otherwise little connection to field work. The linseeds collected along with the stems could be used or sold to produce oil. Safely storing grains from rodents, thieves and other misfortunes over the year may have been a trouble from which the weaver wanted to save himself.

\section{Who were the weavers in Aphrodito?}

Little additional information is found on the social and economic status of weavers (linoüphoi) in the village of Aphrodito. Among the 700 papyri that form the Dioscorus archive, only three other texts mention this profession.
First, P. Cair.Masp. II 67147 (AD 532) is a list of payments for a special levy, which starts with a section related to various professions: first the weavers (col. 1, 1. 3), and then fullers, tool makers, leather workers, sculptors, bakers, oil makers, coppersmiths, clothes menders, barbers, and most certainly others, but the bottom of the papyrus is not preserved. The amounts that each trade had to pay are also damaged, preventing the possibility of any relative comparison of their importance.

The second text, $P$. Cair.Masp. III 67288, is the end of a list of payments by individuals, the exact date and purpose of which are lost. Of around 150 preserved entries, two concern weavers and two others the son(s) of weavers: Pabik (col. 2, 1. 5), NN son of Pkolobos (col. 2, 1. 34), Phoibamōn (sic) son of Thallous (col. 2, 1. 37) and NN son of Patermouthis (col. 5, 1. 17). These men are among the group that pays the lowest rate, one-third solidus, while others pay one-half or a whole solidus. This suggests a rather low social class. The document, however, does not prove any regularity in the paid amounts according to trade: for example, some fullers paid one-third solidus, some one-half, and others one solidus.

Last, a weaver named Andreas is mentioned in a private account, much damaged and to be published by Fournet, without any obvious connection with Dioscorus or flax related activities. ${ }^{33}$

\section{Distinctive features for flax growing seen in Aphrodito}

\section{Specific agricultural agreements}

There is in Dioscorus' archive one other text that explicitly mentions flax growing, this time without the participation of weavers: in P. Cair.Masp. II 67128 (dated of 27 August 547) a deacon of Aphrodito, named Psaïs son of Bēsios and Tasaïs, acknowledges his debt regarding "the rent, seeds,

30. Vogelsang-Eastwood 2000, p. 270 and fig. 11.2. For flax sowing in pre-industrial Europe, see Heuzé 1893, p. 24: "Exécution des semis: On sème la graine de lin à la volée. [...] Cette semaille est difficile. Elle réclame des ouvriers bien exercés, des semeurs qui sachent coordonner le pas avec le bras. Elle n'est parfaite que lorsque la graine a été disséminée très uniformément” (I am grateful to Hélène Cuvigny for this reference).

31. Vogelsang-Eastwood 2000, p. 270. Two examples of New Kingdom representations of harvesting wheat by cutting and flax by pulling out are: Deir el-Medina, tomb of Sennedjem (TT1); Elkab, tomb of Paheri. Another suggestion of this opposition can be found in the vocabulary used: the editor of the Coptic document P. Brux.Bawit 49, Alain Delattre, underlines in his commentary to line 1 that a specific verb, $2 \omega \omega \lambda \epsilon$ meaning "to pluck", is used in particular to refer to flax harvesting, see Crum 1939, p. 667b.

32. Vogelsang-Eastwood 2000, p. 270: "The timing of the harvesting is important, because the age of the plant affects the uses to which the fibres can be put. Thus, if the flax plants are harvested while still young and green, then a fine textile can be produced, and if it is harvested when slightly older, then the fibres are suitable for a general, good quality cloth. However, if the harvesting takes place when the plants are old, then the resulting flax is usable only for coarse cloth and ropes”.

33. P. Lond. inv. 0493 mentioned by Ruffini 2011, p. 610, no. 38. The presence of this individual in P.Lond. inv. o569b (Ruffini 2011, p. 610, no. 39) is now called into question. 
and irrigation" of one aroura that he will cultivate with flax. The land is located in the northern part of Aphrodito's territory, close to a place named "of Athanasia". The due amount is one solidus minus two carats, the same high rent recorded in the weaver contract $P$. Cair.Masp. II 67116. The end of the document bears the mention of a previous agreement between Psaïs and Dioscorus regarding two arourai in an area called Piahse, which is known to be in Phthla. Two years later, in P. Cair.Masp. II 67129 (14 August 549), the same person has become a priest and draws a similar contract, except this time for three arourai. The arourai are in two groups: one is explicitly near the place of Athanasia and the two others are not located, but it is tempting to think that they are the same two arourai in Phthla. The first editor thought that the later document was only to cultivate wheat, because the rent includes a payment in kind. However, the passage mentioning the nature of the growing is damaged and wheat could have been cultivated in one part of the rented plots while flax was in another part. This hypothesis would justify the amount of the rent: it amounts to two solidi, each minus two carats, to which are added one-third solidus and 1.5 artaba of wheat, which corresponds to 11.6 carats, a figure close to the 12 carats that was the regular rent of an aroura planted in wheat. The aroura close to the place of Athanasia would on this occasion be sown with wheat, while the two others would be sown with flax. In this hypothesis, we have a second piece of evidence for flax growing in Phthla in addition to the petition/letter P. Flor. III 296.

As already mentioned, this type of agreement concerning "the rent, seeds, and irrigation" is very rare. In P. Cair.Masp. II 67251 (18 October 549), Iakybis (sic) son of Abraam, also a priest, draws a similar acknowledgement of debt to Dioscorus: the same high rent of one solidus minus two carats for one aroura, to be paid this time at the second levy of taxes. Nothing is said on the location of the plot or on the nature of its cultivation, it is thus possible that it was flax. Would priests be, like weavers, specifically interested in this "all inclusive" agreement due to their limited agricultural activities? There is indeed only one other lease of field in Aphrodito in which a priest may have been the tenant, but it is damaged and incomplete. ${ }^{34}$ A deacon, however, clearly takes on lease a well-planted and equipped property at his own expense in $P$. Lond. V 1696 recto. ${ }^{35}$ The nature of the growing that he will do on the land is not specified, but the rent is 7 artabai of wheat per aroura, a slightly higher rate than usual, probably due to the specific trees and equipment on the rented property.

Howard Comfort studied the group of texts formed by P. Cair.Masp. I 67116, P. Cair.Masp. II 67128, 67129 and 67251 from a juristic point of view. ${ }^{36}$ He underlines that 67128 and 67129 are the real leases, drawn in August, while 67116 and 67251 are acknowledgements of debt when Dioscorus actually gave the seed in October. ${ }^{37}$ A fifth text, P. Mich. XIII 668 (9 July 555), was published after Comfort's study and completes the picture: it is a receipt, also drawn by the same notary, Pilatos, for "the rent, seeds, and irrigation" of two arourai issued by the landlord in July, i.e. after the harvest and threshing. This time, the tenant is Phoibammōn son of Triadelphos, a well-known figure in Byzantine Aphrodito with many agricultural business activities. ${ }^{38}$ Therefore, in his case, the argument that, due to his limited experience, he may have found a higher rent profitable - as long as he did not have to care for the provision of seeds and the irrigation - does not hold. The situation is, however, different: first, the amount is not given and thus it cannot be proved that the rent was higher than a regular one. Second, and most of all, this receipt is in fact an acknowledgement of debt from the landlord to the tenant, because the rent is that of the following year. James Keenan has studied another group of papyri in which Phoibammōn, as the tenant, is seen lending money to his landlord, a soldier named Samuel who descends into deeper and deeper debt. ${ }^{39}$ A last aspect of this receipt needs to be underlined: the two arourai are said to be, in line 3 , in "fat earth" (lipara gē), a rare expression that points to an important parameter that needs to be taken into consideration in the present discussion.

34. P. Cair.Masp. I 67108 (547) is the beginning of a document in which a priest, along with his brother, seems to sublease land belonging to Dioscorus' family. The syntax and lacunas of this text make it difficult to understand what precisely is going on.

35. Jean-Luc Fournet has identified P.Lond. inv. 01603b as belonging to the same document and has edited the verso, see now SB XXVI 16529 (526). Florence Lemaire has produced a preliminary edition of the recto, which is currently unpublished.

36. Comfort 1936, p. 293-299.

37. Comfort surprisingly considers that Dioscorus wrote these documents himself, see Comfort 1936, p. 293: "En étudiant les baux fonciers de cette époque, j'ai été frappé par plusieurs documents de sa main”. They are, however, signed by a notary named Pilatos, see Diethart \& Worp 1986, p. 30-31. Therefore parts of Comfort's argument about the young Dioscorus trying new juridical ways and later learning from his trip to Constantinople (p. 298-299) need to be taken with caution.

38. Fournet 2016 p. 115-141 on Phoibammōn's archive, which differs from Dioscorus' one; Keenan 1980, p. 150-154 on Phoibammōn's business.

39. Keenan 1980, p. 145-150. 


\section{Specific settings}

This expression "fat earth" is only attested in four papyri: P. Vat.Aphrod. 1, the already discussed P. Mich. XIII 668, P. Cair.Masp. II 67128, and 67129. Before returning to the two latter texts, the former requires a brief summary. P. Vat.Aphrod. 1 (23 April 598) is a land lease of a large, well-equipped property, the rent of which conforms with the regular rate, in line 19-20, of five artabai of wheat per aroura. This contract contains several specific stipulations, among which, in line 22, the fact that the landlord should receive the full product of two arourai that have to be taken, one in "fat earth", the other in a "wheat-bearing plot" (sitophoron gēdion). The adjective sitophoros meaning "bearing wheat" is abundantly attested between the $2^{\text {nd }}$ century $\mathrm{BC}$ and the $2^{\text {nd }}$ century $\mathrm{AD}$ to qualify $g \bar{e}$, "earth", and refers to arable land, grain land. From the $3^{\text {rd }}$ century $\mathrm{AD}$, it becomes rare and the three occurrences in the Aphrodito papyri are the more recent ones. In addition to leaving the entire product of two arourai to the landlord, the tenant will have, in line 24, to fertilise one aroura (possibly the one in the wheat-bearing plot) and he will pay, in lines 26-27, three solidi each minus one carat. In exchange for the produce from these two arourai and the given money, the tenant will receive ten arourai free of rent, representing for him a saving of 50 artabai, i.e. 5 solidi. This shows that the two arourai kept by the landlord are both worth 1 solidus each, a rate that recalls the one seen in the leases mentioning flax growing, among which are P. Cair.Masp. II 67128 and 67129.

The two contracts, P. Cair.Masp. II 67128 and 67129, between Psaïs, the deacon and later priest, and Dioscorus include a specific indication as to where flax should be cultivated. The expression in both texts is damaged: in 67128,

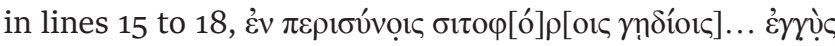
$[\lambda ı \pi \alpha \rho \hat{\alpha} \varsigma(?)] \gamma \hat{\eta} \varsigma$ and in 67129, in lines 14-15: '่́v $\pi \varepsilon \rho[1] \sigma u ́ v o v$

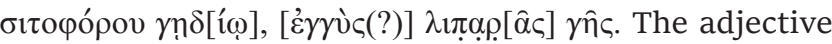
perisunos ( $\pi \varepsilon \rho$ íбvvo $)$ was interpreted by the first editor as meaning "surroundings". $4^{\circ}$ The rented aroura( $\left.i\right)$ would then have been next to wheat-bearing plot(s) and close to "fat earth". S.G. Kapsomenakis argued that this form comes instead from perusi ( $\pi \varepsilon ́ \rho \cup \sigma \mathrm{l})$, which is well attested in
Classical Greek and means "a year ago, last year". ${ }^{41}$ The reading of the adverb eggus meaning "close to" is very tentative in 67128 and restored in the lacuna in 67129. It can be deduced from $P$. Vat.Aphrod. 1 that the two categories differ. The meaning must therefore be that the land had been cultivated with wheat the year before and its soil was now in the state of being "fat". This indicates a justified crop rotation for flax, since, according to Pliny, "no other plant grows more quickly: it is sown in spring and plucked in summer, and owing to this also it does damage to the land". ${ }^{2}$ The concern of not exhausting the soil could then explain why Psaïs would have sown flax near the place called Athanasia in $\mathrm{AD}$ 547 (P. Cair.Masp. II 67128) and in the two arourai in Phthla in AD 549 (P. Cair.Masp. II 67129). This suggests that Dioscorus had agreements for crop rotations in his various fields. The same idea is found in the lease P. Oxy. XLV 3256 (Oxyrhynchos, $\mathrm{AD}$ 317-318): of 26 arourai owned by the landlord, the tenant rents, to sow flax, only the 13 arourai "which are lying fallow" (tas en anapausi ousas) in line 8.

An explanation for these two kinds of soil is given in a passage by Galen ${ }^{43}$ in which cereal land (cultivated with wheat and barley) is opposed to land in which trees grow (vines, fig trees, olive trees), the latter being called lipara $g \bar{e}$, because of the presence of clay (pēlos). The Greek word for clay is, to my knowledge, not present in leases, but in a $7^{\text {th }} / 8^{\text {th }}$ century AD Coptic document, the leasehold property dealt with in the text is formed by "two plots of clayland under the sloping ground". 44

Pliny describes the suitable soil for flax as follows: "flax is chiefly grown in sandy soils, and with a single ploughing". ${ }^{45}$ Katherine Blouin, however, has discussed this assertion: "Pliny's claim regarding the suitability of sandy soils to flax culture must be nuanced in the light of modern knowledge on the biology of flax, which shows that the best-suited soils for this crop are heavy, loamy ones that retain water". ${ }^{6}$ She provides the following precision: "Loam is a type of soil made of 7 to $27 \%$ of clay, 28 to $50 \%$ of silt, and less than $52 \%$ of sand". ${ }^{47}$ This definition, showing the presence of clay, fits well with Galen's description of lipara $g \bar{e}$.

If "fat earth" is where trees could be planted, it needs to be in a specific location. One could also wonder if "fat earth"

40. P. Cair.Masp. II 67128, p. 9, commentary to line 5: "Le mot doit signifier 'les environs' ”.

41. Kapsomenakis 1938 , p. 64-65, n. 2.

42. Pliny, NH, 19, 2, 7.

43. Galen, $S M T, 9,165$.

44. O. CrumST 37, 5-6 mentioned in Richter 2009, p. 208.

45. Pliny, $N H, 19,2,7$.

46. Blouin 2014, p. 234.

47. Ibid., p. 234, n. 87. 
could have been the result of a particular preparation of the plot, which would be covered by floodwater longer than the other cereal lands. In the Description de l'Égypte, the memorandum about contemporary agriculture gives the following information: "Comme toutes les terres inondées naturellement ne sont pas situées au même niveau, on réserve les plus basses, sur lesquelles les eaux ont séjourné le plus longtemps, pour la culture du lin [Linum usitatissimum]". ${ }^{8}$ The cases of "fat earth" in Aphrodito were not all located in a single spot, but were scattered either in the northern part of the village territory (the place of Athanasia in $P$. Cair. Masp. II 67128), in the eastern part (P. Vat.Aphrod. 1), or even further to the east in Phthla ( $P$. Flor. III 296 and possibly P. Cair.Masp. II 67129), a village whose territory did not reach the Nile. ${ }^{49}$ Some areas may have been in a lower level, close to key points of the irrigation system, about which little is known..$^{\circ}$ The only mention of irrigation equipment in these texts is that the aroura in fat earth is "south of the cistern" (lakkos), while the wheat-bearing plot is "east of the dyke, south of the great channel" (amara) in P. Vat.Aphrod. 1, 22-23. Special preparation of the land before the end of the flood period would explain that agreements concerning flax growing had to be made in August ( $P$. Cair.Masp. II 67128 and 67129).

The Description de l'Égypte provides further information: "[Dans la province de Syout], le lin est semé au solstice d'hiver. La terre, qui a été submergée naturellement, ne reçoit aucune préparation. La meilleure est celle qui a été le plus longtemps inondée : comme alors elle est à l'état de boue, la semence s'y enfonce assez pour n'avoir pas besoin d'être recouverte. [...] Les champs ensemencés en lin n'exigent aucun soin jusqu'à la récolte. Elle se fait au commencement d'avril, trois mois et demi après les semailles". ${ }^{51}$ There are, however, some discrepancies with the picture drawn from the Aphrodito papyri: sowing seems to have occurred in October rather than December and, more important, flax needed more watering than that provided by the Nile flood alone. This is confirmed by a Coptic lease,
P. Mon.Epiph. 85, in which two men take on lease land from a priest and agree to "sow two fields with flax for you [...] and work them with the farmer's craft and to give them their waters". ${ }^{2}$ Considering the Greek documentation, John R. Rea underlined: "In eleven of our thirteen leases the text allows us to deduce that there was an unusually good supply of water", 53 with mention of land being near to an irrigation machine or associated with embankments of irrigation works or even located in the marsh (en tō helei). ${ }^{4}$

Evidence of flax growing from Oxyrhynchos is mostly from the Leonides archive (TM Arch 132) 55 and would require a detailed analysis that goes beyond the purpose of the present paper. The case of the village of Ision Panga, however, stands out, with five flax leases located in its territory. On the basis of what has just been demonstrated for Aphrodito, and flax growing in general, one would expect rich soil and a good water supply. Jane Rowlandson, however, described the village as follows: "But towards the desert edge agricultural prosperity declined. Ision Panga had more than its fair share of problems, with land sanded over, land damaged by floods, and more evidence of fodder than of cereal crops". ${ }^{56}$

\section{Conclusion}

Texts from Dioscorus' archives provide precise insights into flax growing in an Egyptian village. In many cases, the practice of subsistence farming explains why this crop is not as visible as may be expected from the vast linen trade that operated in Egypt. As with vegetables, flax must have been cultivated on small plots together with wheat. When flax was grown on a large scale, Aphrodito papyri suggest that it was in a median position between wheat and vine farming: it was done on cereal land, but required some specific treatments, one being "fat earth", the other good irrigation. The need to rotate crops in order not to exhaust the land would explain that plots could not be registered as flax land for specific taxation. From

48. Girard 1809-1829, §11 p. 539.

49. The location of the property concerned with P. Vat.Aphrod. 1.

50. On this subject, see Marthot 2016b, p. 1871-1885.

51. Girard 1809-1829, §11 p. 540.

52. Wilfong 1999, p. 219-220.

53. P. Coll.Youtie II 68, introduction p. 459.

54. P. Herm. 22, 11 (Hermopolis, AD 394); see also P. Coll.Youtie II 68, line 18-22: “[We undertake to lease your land]... on condition that we... are to have, rent free, for the retting of the flax, the reservoir (limnē) which you possess ...close to the cistern (lakkos) of Diogenis and which is within (?) the pool (charubdis) of Pasiniscus". Charubdis is a rare word also found in fishing contexts.

55. Luijendijk 2010, p. 575-596.

56. Rowlandson 1996, p. 18. 
the tenant's point of view, weavers may have found it convenient to grow flax themselves, but that could also be true for other social categories, including deacons and priests who willingly chose this plant cultivation. From a landlord's point of view, having tenants cultivating flax seems to have been a lucrative business and a practical way to pay the taxes due in gold. As there were not so many weavers in a given village, rivalry at times erupted among landlords, even leading some of them to procure this type of agreement by force. This battle over flax sowing is a telling illustration of the economic significance of this crop in the village microcosm.

\section{Abbreviations}

All papyrological works and all references to papyri, ostraca, etc. follow J.F. Oates, R.S. Bagnall, S.J. Clackson, A.A. O’Brien, J.D. Sosin, T.G. Wilfong \& K.A. Worp (eds.), Checklist of Greek, Latin, Demotic and Coptic Papyri, Ostraca and Tablets. Available at: https://library.duke.edu/rubenstein/scriptorium/ papyrus/texts/clist_papyri.html (continually updated)

\section{Ancient Sources}

Pliny, Natural History. Ed. Rackham H., Jones W.H.S. \& Eichholz, D.E. 1949-1954, Cambridge.

Galen, De simplicium medicamentorum temperamentis ac facultatibus libri XI, in Galeni Opera Omnia, 20 vol. Ed. Kühn K.G. 1821-1833. Leipzig (reprinted in 1965 by Georg Olms AG-Verlag, Hildesheim).

\section{Bibliography}

Banaji, J. (2001) Agrarian Change in Late Antiquity. Gold, Labour, and Aristocratic Dominance, Oxford.

Blouin, K. (2014) Triangular Landscapes: Environment, Society, and the State in the Nile Delta under Roman Rule, Oxford.

Bransbourg, G. (2016) "Capital in the Sixth Century: The Dynamics of Tax and Estate in Roman Egypt”, Journal of Late Antiquity 9/2, p. 305-414.

Comfort, H. (1936) "Dioscore d'Aphroditô: cinq locations de terres”, Revue des Études Grecques 49, p. 293-299.

Cromwell, J. (2017) “The Threads that Bind Us. Aspects of Textile Production in Late Antique Thebes", in C. Di Biase-Dyson \& L. Donovan (eds.), The Cultural
Manifestations of Religious Experience, Studies in Honour of Boyo G. Ockinga, Münster, p. 213-224.

Crum, W. (1939) A Coptic Dictionary, Oxford.

Delattre, A. (2018) "Papyrologica 63", Chronique d’Égypte 93 (fasc. 185), p. 212-215.

Diethart, J. \& Worp, K. (1986) Notarsunterschriften im byzantinischen Ägypten, Vienna.

Fournet, J.-L. (ed.) (2008) Les archives de Dioscore d'Aphrodité cent ans après leur découverte, histoire et culture dans l'Égypte byzantine. Actes du Colloque de Strasbourg, 8-10 décembre 2005. Études d'archéologie et d'histoire ancienne, Paris.

Fournet, J.-L. (2016) "Sur les premiers documents juridiques coptes (2): les archives de Phoibammôn et de Kollouthos", in A. Boud'hors \& C. Louis (eds.), Études coptes XIV. Seizièmes journées d'études coptes (Genève, 19-21 juin 2013). Cahiers de la Bibliothèque copte 21, Paris, p. 115-141.

Georgacas, D. (1959) “Greek Terms for 'Flax,' 'Linen,' and Their Derivatives; And the Problem of Native Egyptian Phonological Influence on the Greek of Egypt", Dumbarton Oaks Papers 13, p. 253-269.

Gil, M. (2004) "The Flax Trade in the Mediterranean in the $11^{\text {th }}$ c. as seen in Merchants' Letters from the Cairo Geniza”, Journal of Near Eastern Studies 63, p. 81-96.

Girard, P. (1809-1829) "Mémoire sur l'agriculture, l'industrie et le commerce de l'Égypte”, Description de l'Égypte, État Moderne II, Paris, p. 491-589.

Heuzé, G. (1893) Les plantes industrielles. I Plantes textiles ou filamenteuses de sparterie, de vannerie et à carder, Paris.

Kapsomenakis, S.G. (1938) Voruntersuchungen zu einer Grammatik der Papyri in der nachchristlichen Zeit, Munich.

Keenan, J. (1980) “Aurelius Phoibammon, Son of Triadelphus: a Byzantine Egyptian Land Entrepreneur", Bulletin of the American Society of Papyrologists 17, p. 145-154.

Luijendijk, A. (2010) "A New Testament Papyrus and Its Documentary Context: An Early Christian Writing Exercise from the Archive of Leonides (P.Oxy. II 209/ 10)", Journal of Biblical Literature 129/3, p. 575-596.

Marthot, I. (2016a) "La toponymie d'un village de Moyenne-Égypte et de sa campagne aux VI ${ }^{\mathrm{e}}$ et VIII ${ }^{\mathrm{e}}$ s. apr. J.-C., le cas d'Aphroditê dans l'Antaiopolite d'après les papyrus grecs", in Å. Engsheden \& Y. Gourdon, (eds.), Études d'onomastique égyptienne. Méthodologie et nouvelles approaches. Recherches d'archéologie, de philologie et d'histoire 38, Cairo, p. 161-175. 
Marthot, I. (2016b) "L'irrigation des terres du village d'Aphroditê à l'époque byzantine”, in T. Derda, A. Łajtar \& J. Urbanik (eds.), Proceedings of the $27^{\text {th }}$ International Congress of Papyrology (Warsaw 29 July - 3 August 2013), Warsaw, p. 1871-1885.

Marthot, I. (forthcoming) Un village égyptien et sa campagne: étude de la microtoponymie du territoire d'Aphroditê (VI ${ }^{e}-V I I I^{e}$ s.), [unpublished PhD thesis under the supervision of Professor Jean-Luc Fournet, defended in 2013 in École Pratique des Hautes Études.]

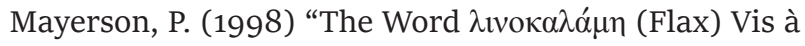

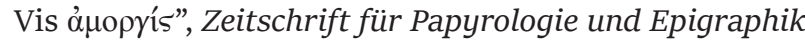
121, p. 223-225.

Richter, T. (2009) “The Cultivation of Monastic Estates in Late Antique and Early Islamic Egypt: Some Evidence from Coptic Land Leases and Related Documents", in A. Boud'hors, J. Clackson, C. Louis \& P. Sijpesteijn (eds.), Monastic Estates in Late Antique and Early Islamic Egypt. Ostraca, Papyri, and Essays in Memory of Sarah Clackson. American Studies in Papyrology 46, Cincinnati, p. 205-215.
Rowlandson, J. (1996) Landowners and Tenants in Roman Egypt: The social relations of agriculture in the Oxyrhynchite nome, Oxford.

Ruffini, G. (2011) A Prosopography of Byzantine Aphrodito. American Studies in Papyrology 50, Durham.

Vogelsang-Eastwood, G. (2000) “Textile”, in I. Shaw \& P. Nicholson (eds), Ancient Egyptian Materials and Technology, Cambridge, p. 268-298.

Wilfong, T. (1999) "Agriculture among the Christian Population of Early Islamic Egypt: Practice and Theory”, in A. Bowman \& E. Rogan (eds.), Agriculture in Egypt from Pharaonic to Modern times, Oxford, p. 217-235.

Wipszycka, E. (1965) L’industrie textile dans l'Égypte romaine. Archiwum Filologiczne 9, Wrocław - Warsaw - Cracow. 